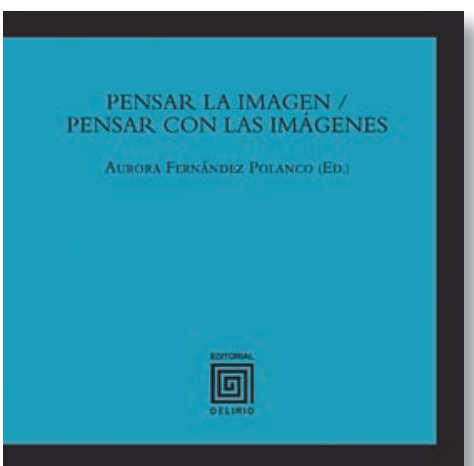

\title{
Aurora Fernández Polanco (ed.) \\ Pensar la imagen/pensar con las imágenes.
}

Salamanca: Delirio, 2014.

\section{Por César Paredes Peña \\ Universidad de Salamanca. Salamanca, España. \\ canparedes@gmail.com}

La saturación de imágenes en un mundo hipermediatizado e hiperinformado dificulta entrever su papel en la producción de conocimiento. Las imágenes que navegan por la red se multiplican sin parar, alteradas, compartidas, reapropiadas o subvertidas. El vértigo que genera su sobreproducción obliga a repensar su papel político y social. ¿Cómo recuperar la imagen?, ¿cómo abordarla críticamente?, ¿cómo reescribirla cuando ha derivado en narrativas oficiales y hegemónicas? Estas son algunas cuestiones que el proyecto I+D "Imágenes del arte y reescritura de las narrativas en la cultura visual global" encara en la compilación de ensayos intitulada Pensar la imagen/pensar con las imágenes.

La mayoría de los investigadores que participaron en su producción están vinculados a la Universidad Complutense de Madrid como profesores o investigadores: Aurora Fernández Polanco (editora e investigadora principal), Josu Larrañaga, Jaime Vindel, Loreto Alonso, Pablo Martínez, Fernando Baños y Carlos Fernández, María Ínigo y Natalia Ruiz. Daniel Lupión es profesor en la Universidad Rey Juan Carlos, Santiago Lucendo en la Universidad Europea de Madrid, Tania Castellano en la Universidad de Zaragoza y Yayo Aznar de la Universidad Nacional de Educación a Distancia de Madrid. Diana B. Wechsler es investigadora independiente del CONICET de Argentina. 
Desde sus distintas miradas los investigadores advierten los desafíos que supone para la reflexión estética el proceso de producción, consumo y distribución del arte en medio de la revolución tecnológica. El libro se inserta en el debate académico sobre cuál es el papel del artista, de la enseñanza artística, de los museos, de la curaduría y de las propias imágenes en la construcción social de la mirada. La apuesta es benjaminiana en tanto que actualiza observaciones enunciadas por el teórico que anticipó la cuestión tecnológica para la comprensión política, social y filosófica de la imagen.

El primer artículo, "Imágenes/arte en la sociedad del rendimiento", de Larrañaga, refiere cómo el espectador ávido de experiencias queda a merced del capitalismo y su obsesión por rentabilizarlo todo. El nuevo modelo social genera una crisis en la recepción estética: el público es obligado a generar un espacio de sí mismo, convirtiéndose en productor de sentido; pero a la vez queda "sin abrigo, a la intemperie" (27), desnudo y expuesto al control disciplinario. Como alternativa están las experiencias de colectivos artísticos que promueven los encuentros con el otro.

A partir del cine de Pasolini, quien abogó por el rescate de lo subalterno, Vindel en "La imagen de las cosas: cuerpo y objeto ante la crisis del consumo" propone una sugerente conciliación de los relatos de la micropolítica y la macropolítica. Las expresiones de la micropolítica inspirada fundamentalmente en el "acontecimiento" -muchas veces romantizado- no son necesariamente excluyentes respecto de la "representación", aduce. La imagen performativa que exalta el acontecimiento merece una crítica igual a la de la democracia directa ligada al liberalismo más rampante.

"Un acercamiento a interfaces húmedos", de Alonso, desentraña el papel de las plataformas tecnológicas en el proceso de mediación, multiplicación y movilidad de las imágenes. La comunidad de espectadores pasó a reconfigurarse en la cultura visual global como "audiencias fragmentadas en las que los cuerpos se encuentran en tránsito y las imágenes en disolución y recombinación constante” (95). La intensidad y velocidad con la que las imágenes se transmiten, aparecen y desaparecen impiden su reconocimiento reflexivo. Con agudeza, Alonso señala cómo la imagen y las interfaces tienden a fundirse, adquiriendo un lugar en la vida cotidiana y replanteando conceptos como "lo natural y lo artificial"; proceso de hibridación que impone desafíos en todas las áreas de conocimiento.

En “15M. Acontecimiento y representación”, Lupión denuncia la capacidad del sistema capitalista de absorber las "representaciones" de los movimientos sociales y reducirlos. Desde la experiencia del movimiento Indignados (o 15M), en España, explica cómo funcionan esos mecanismos. Un ejemplo es la cobertura que hizo el portal periodístico elespectador.com del aniversario del $15 \mathrm{M}$, que publicó una galería fotográfica de "las mejores pancartas". Lupión condena los "mecanismos de separación" de las imágenes de la multitud por "extremadamente insidiosos", pero pasa por alto que el medio es colombiano y que retoma el acontecimiento para ponerlo en la agenda noticiosa de un país cuyas audiencias podrían estar poco interesadas en el hecho. En cambio, intuye "la orden de una predeterminada sensibilidad e inteligibilidad hacia el 
$15 \mathrm{M}$ a la que pretenden someternos" (114). Así, cae en el lugar común de atacar a los medios de comunicación bajo un prejuicio extendido pero no demostrado, en este caso.

Dos preguntas recorren el ensayo "La abstracción de la masa" de Martínez Fernández: cómo recuperar la imagen de la clase trabajadora y de qué manera "la masa" puede resistir a la cooptación de su imagen por el sistema. Argumenta que en los actos políticos masivos la identidad se "emborrona para conformar un nosotros" (161) que trasciende lo identitario. Ese gesto de abandono del yo desvirtúa la romantización del acontecimiento e impide que conceptos como "masa", "pueblo" o "multitud" engloben con suficiencia su imagen. Sobre cuál es la mejor forma de concebirla desde el arte, sugiere una propuesta: "la abstracción, la repetición y la multiplicación, mediante una operación que borre los límites y desenfoque la concreción de las cosas” (168).

Es sabido que las imágenes monstruosas representan el horror y el abuso del poder, recuerda Lucendo en "Pensar con las imágenes. Pensar con el monstruo". Lo monstruoso siempre entraña la necesidad de interpretación, ya sea por hostil o por resistente. Hobbes ilustró El Leviatán con un monstruo formado por la masa, que luce una corona y símbolos eclesiales, cuya imagen domina el paisaje, y Karl Marx se valió del fantasma para desactivar el temor al comunismo en Europa. El autor propone la figura del Kraken para representar el poder actualmente, figura que se mueve en hábitats líquidos y cuyos tentáculos se asemejan a los de las corporaciones.

En "Nuestras imágenes: Breve genealogía de un conflicto disciplinar", Fernández Polanco da cuenta del desafío contemporáneo de la enseñanza de la historia del arte, cuya tradición ha sido esteticista e historicista. Recuerda cómo durante la dictadura franquista los estudiantes se alejaron de la comprensión del arte. "Solo en los últimos años hemos comenzado a pensar que las clasificaciones y jerarquías, los cánones marcados, encerraban al otro en una narrativa colonial y dotaban a la modernidad occidental de un discurso construido por voces y tópicos autoritarios" (213). Como docente, discrepa de la producción de conocimiento basada en la "representación", cuando la performatividad de las imágenes y su carácter dialógico en un mundo atravesado por nuevas tecnologías ha cobrado una importancia insoslayable.

El cine de László Krasznahorkai y Bela Tarr sirve a Baños para descubrir los mecanismos con los que se produce la "contemplación pura" y la "contemplación activa”. Su artículo "El actor-espectador y el espectador-actor: contemplación, distanciamiento y catarsis cinematográfica" aboga por una estética que invite a la acción. Al respecto, explica que la "contemplación pura", concepto acuñado por Schopenhauer, se da cuando un espectador se abandona a observar sin ninguna voluntad de hacerlo. En cambio, cuando el espectador es obligado, a partir de un distanciamiento, a la reflexión, a tomar posición, la contemplación lo devuelve a su propia realidad y no lo deja impasible, para producir una "catarsis crítica".

En "Be water, my friend. El oleaje como recepción de las imágenes del arte”, Castellano dilucida la relación entre los espectadores y la obra artística. Hay obras que envuelven con su oleaje al espectador, y otras que lo sacuden y engendran un oleaje 
desde el espectador. La metáfora da lugar a un análisis sobre la cresta -o momento de auge de la obra- y el valle, cuando el arte ha quedado desgastado por la acción del público. El oleaje global se convierte en tsunami que arrasa mientras en otro lado el sujeto, consciente de su situación social, promueve un oleaje en distinto sentido. "Lo vital para el espectador es salir a flote" (270), dice, unas veces resistiendo la corriente y otras dejándose llevar para remontarla.

Para la biología, el efecto mimético que exagera la necesidad de camuflaje de los animales se llama hipertelia. En "La selva documental: «hipertelia» texto e insignificancia en las imágenes de Burden of dreams", Fernández Pello toma prestada esa categoría para identificar la superposición de las imágenes de la historia, la ficción y el documental. En el relato de Carlos Fermín Fitzgerald, el cacique del caucho, se da esa saturación obsesiva: Werner Herzog escribió la Conquista de lo inútil (2010) e hizo la película Fitzcarraldo (1982) y Les Blank realizó el documental detrás de cámaras Burden of dreams (1982). La realidad, desplazada por imágenes performativas y documentales, y revisada en un libro, se asemeja a ese fenómeno de la naturaleza y genera "un conocimiento reflexivo e hiperbólico" (283).

En "La mirada de Foucault", Aznar sostiene que el filósofo no usó imágenes para hacer su Historia de la locura en la época clásica, salvo algunas de Francisco de Goya que convenían a su revisión del control biopolítico de la psiquiatría. No incluyó las pinturas de cinco "monomaniacos" que le encargó el psiquiatra Étienne-Jean Georget a Théodore Géricault, a pesar de que dedica un capítulo a la concepción de la monomanía como enfermedad. Estas pinturas son ambiguas y no permiten concluir que se trata de enfermos mentales sino de personas con miradas melancólicas. Su "opacidad" podía afectar el análisis de las representaciones de Foucault, quien las descartó, pero a la vez testimonian "el dominio potencial de la psiquiatría sobre toda la población” (317). La observación conduce a la pregunta sobre cómo miraba Foucault la pintura y la fotografía, lo que también demuestra que desde la indeterminación y latencia de las imágenes se puede poner en duda el conocimiento en sí o producir nuevos conocimientos.

“Tajos en la historia: Intelectuales y el poder en el cine entre Cuba y Brasil en torno a 1973", de Íñigo, examina intersticios de la historia del cine de ambos países. Producciones como Memorias del subdesarrollo (1968) de Tomás Gutiérrez Alea, Coffee Arábiga (1968) de Nicolás Guillén, El otro Francisco (1974) de Sergio Giral, Terra em transe (1967) de Glauber Rocha, Os inconfidentes (1972) de Joaquim Pedro de Andrade o Congo (1972) de Arthur Omar ponen en entredicho las versiones oficiales -e intelectuales- sobre los relatos de la nación de Cuba y Brasil, revisando el pasado y reformulando miradas sobre la identidad, lo popular y lo colonial. Sorprende cómo estas películas se anticipan a debates sobre la reescritura de la historia. Íñigo propone una disección foucaltiana en "tajos" de la historiografía para redescubrir esas narrativas.

"El museo como mirada y como relato", de Ruiz, es a mi juicio el artículo más flojo. Comienza con la historia de los museos pero pronto la abandona sin desarrollar una 
hipótesis. Sugiere que, a pesar de que las nuevas tecnologías facilitan la divulgación de imágenes, la contemplación de las obras se dificulta cada vez más, pero no explica por qué. Esgrime el problema de la crisis económica como causa de la inasistencia a los museos sin ofrecer una cifra de los precios de entrada o de los recortes de las subvenciones que sostenga su opinión. Además, cada dos páginas anticipa qué es lo "más preocupante" $(363,365,367)$, sin acabar de demostrarlo.

Finalmente, el artículo "Curadurías, montajes, in-disciplinas" de Wechsler explora un abordaje del trabajo curatorial que subvierta los relatos instituidos, ilumine los sentidos y libere las miradas; montajes basados en procesos de investigación que permitan pensar con las imágenes. Una propuesta original basada en experiencias de la autora.

Pensar la imagen/pensar con las imágenes pasa revista a debates académicos urgentes sobre el papel político de la imagen. Es un libro necesario para su comprensión como parte del entramado social y tecnológico, cuyos cambios acelerados trastocan la producción de sentido y nuestra capacidad de reflexión. 